\title{
WILDLAND INVENTORY AND MAPPING ${ }^{1}$
}

\author{
By D. 5. LACATE ${ }^{2}$
}

RESUME

On s'intéresse actuellement à des systèmes de classification et de cartographie des terres qui soient suffisamment élaborés pour permettre de planifier rationnellement la mise en valeur des terres. L'auteur passe en revue les divers programmes et systèmes d'inventaire des contrées sauvages au Canada. Il trace les grandes lignes d'une méthode d'approche pour diviser en grandes unités écologiques les terrains destinés à la foresterie, à la faune et à la flore, à la récréation ou à l'agriculture.

\section{$A B S T R A C T$}

Present interest in land use planning is drawing attention to the necessity for land classification and mapping systems that will serve as a basis for rational land use decisions. Various programs and approaches to the inventory of wildlands throughout Canada are reviewed. An approach for dividing landscapes into ecologically significant units for forestry, wildlife, recreation and agricultural purposes is outlined.

\section{INTRODUCTION}

The rational utilization of land resources must be preceded by a knowledge of their nature and their extent. A rising interest in land use planning is drawing attention to the need for suitable physical land classification and mapping systems that will provide a basis for national decisions as to land use and land management. This paper, which was prepared to lead the discussion on the formation of a Sub-Committee on Wildland Inventory and Classification, reviews the various methods that have been taken to wildland inventory, and proposes an approach that may be useful in assessing the multiple uses of land for forestry, wildlife, recreation, water and agriculture.

The term "Wildland" has been suggested in place of "Forest Land" because use of the latter term could lead to misinterpretation of objectives by personnel in other disciplines interested in the same land areas. Many excellent definitions of "Forest Land" and "Wildland" have been presented (e.g., Hills, 1961) and we should endeavour to develop a suitable statement in the near future. For the present, I have interpreted "Wildlands" to be the area of Canada that is basically unsettled and is situated outside the general rural, agricultural

\footnotetext{
'Prepared for Meeting of the National Committee on Forest Land, Ottawa, January 26-27, 1966.

${ }^{9}$ Research Officer, Dept. of Forestry of Canada, Forest Research Laboratory, Victoria, B.C.
} 
and urban areas. In other words, wildlands are those land areas that are not included in the present terms of reference of ARDA sponsorship; ARDA sponsorship of capability classification for forestry, recreation, and wildlife purposes is presently restricted to lands where there is a potential development for, or conflict with agriculture.

\section{Need For Wildland Classification For Forestry Purposes}

Forest productivity, regeneration and silvicultural studies in this country have only been very loosely related to a well-defined geographic stratification of land or soils. This is due, in part, to the lack of adequate cooperation between foresters and soil scientists, and also to the fact that a systematic survey of wildlands is lacking in most regions.

Foresters are recognizing that they must become concerned with the management of wildlands for purposes other than wood production. Spurr (1964) noted that "if the forester restricts his objectives solely to timber production his profession will become merely one of a group of professions concerned with the management of wildlands", and he concludes that if foresters are not prepared to accept their responsibilities in land management of all sorts, they may only pass the torch to others who may be less qualified to carry out the task.

Bickerstaff (1963) stated that information on the capabilities of wildlands for forestry is sketchy at present because forest surveys have been concerned primarily with the inventory of the forest crop rather than with its land base. Foresters and forestry agencies are working on ways and means of assessing the land itself, and he notes that the Federal Department of Forestry is keenly interested in the problem and feels that a co-ordinated effort by foresters, forest soil specialists, agricultural soil surveyors, geologists, and geographers may be required for its solution on a national basis. The formation of this National Committee on Forest Land, a result of the unanimous resolution of federal, provincial, and university delegates who attended a national meeting held in January 1965, reflects the interest that is developing.

Perhaps the goal that foresters should consider is the one presented by Staebler (1965) who stated that "Since forest land is the land to be managed, it is appropriate that forestry be the profession of forest land management." As foresters become more receptive to the concept that they are involved with the management of the land and its renewable resources it is clear that basic land inventory and ecological landscape studies will be a necessity for rational land use and management.

\section{Present Status}

Before we consider a proposed methodology I would like to summarize some of the work in land inventory and mapping (on wildlands) that has been completed, or is under way in Canada. It would not be possible to present a review of all the programs in the short time available at this meeting; therefore, I have limited my outline to some of the highlights of the programs that 
various organizations have initiated. I have also restricted my selection of references to those that are primarily concerned with land inventory and mapping of specific areas of land, and have therefore omitted many excellent research papers on the discussion of techniques, and the study of soil properties and other physical factors as related to land productivity and forestry practices.

In British Columbia the number of square miles of wildlands that have been inventoried in a systematic survey is very small. Cooperative surveys of forest land involving Federal and Provincial Departments of Forestry and Agriculture, and using a combined landform-soil-vegetation approach at various scales, have been completed on selected pilot study areas (Sprout et al. 1964; Spilsbury et al. 1965; Lacate et al. 1965). A demonstration survey was also completed in cooperation with the University of British Columbia (Lacate 1965). Perhaps the largest area of wildlands that has been mapped in B.C. is the Princeton-Tulameen map-sheets surveyed by the Canada Department of Agriculture, Soil Survey division, in Vancouver. This report will be published in the near future. The Department of Mines and Technical Surveys has also started on a program of Surficial Geology mapping in the southern interior and several map sheets, which include a sizeable acreage of forested lands, have been completed (e.g., Fulton 1962). These surficial geology maps provide an excellent framework for future studies of soil and vegetation classifications.

Land classifications of wildlands in Alberta have been initiated by various organizations. The significance of landforms in the evaluation of forest land has been outlined for a portion of the Foothills Region (Gimbarzevsky 1964). The Department of Forestry in cooperation with other agencies has mapped selected areas, examined the productive capacity of various soils series, and studied the relationships between soil-vegetation-landform classifications (Critossley 1951; Jeffrey et al. 1964; Duffy 1965). The Department of Mines and Technical Surveys is also undertaking the mapping of surficial geology in selected areas. An exploratory soil survey of northern Alberta has been completed by the Alberta Research Council (e.g., Odynsky et al. 1961), and portions of the Northwest Territories have been examined by the Federal Department of Agriculture (Leahey 1953; Day and Leahey 1957).

The Federal and Provincial soil survey organizations and the universities in Saskatchewan and Manitoba have produced, for example, at a broad scale, a physiographic and soil map of the Northern Provincial Forests (Saskatchewan Soils Survey 1960), and at a more detailed level, the soil survey of southeastern Manitoba (Smith et al. 1964). A section on forest productivity and ease of reproduction ratings for various soils was prepared by the Department of Forestry in this latter report.

Soil and minor vegetation types in southeast Manitoba have also been studied by Ritchie (1961), and demonstration mapping techniques based on landform patterns and habitat types were completed by Mueller-Dombois and Jameson (1963).

The largest areas of wildlands that have been mapped in any detail are in Ontario where Hills and his colleagues have had an active program under way for many years (e.g., Hills et al. 1960; Hills and Pierpoint 1960; 
Pierpoint 1962; Lynn and Zoltai 1965). The approach used in these surveys stresses the use of landform and physiography as the integrating framework for features of the vegetation, soil, and climate.

Several demonstration areas have been classified and mapped on the basis of landform alone, and landform, soil and vegetation in various parts of Quebec (Brown 1956; Jurdant 1964a; Jurdant 1964b). Areas surveyed by Federal and Provincial Soil Survey organizations in eastern Canada and the Atlantic provinces include a varying amount of forested lands or wildlands (e.g., Lajoie 1960). These surveys are, of course, based on the soil classification proposed by the National Soil Survey Committee (N.S.S.C.). The Department of Mines and Technical Surveys is also carrying out surficial geology studies in the Atlantic provinces (e.g., the Surficial Geology of Fredericton, York and Sunbury Counties by H. A. Lee), and reports for various areas are available.

The Department of Forestry has prepared land type maps for a part of western Newfoundland using aerial photography (Damman 19593); and mapping of forest site types has been attempted by Bajzak (1964) on an experimental area near Stephenville Crossing.

There are many other pilot studies on "wildlands" that have been undertaken by the universities or sponsored by other organizations (Blake 1953"; Hare 1959) and I would refer you to the review prepared by Tomlinson (1963) for a partial list of papers. Other sources that I have not attempted to review are the numerous unpublished case histories and special projects completed by consultant services and companies throughout the country. Finally, at the national level there are small portions of "wildlands" included in many of the ARDA soil capability for forestry projects reviewed at this meeting, but these data and maps, as yet, have not been published.

The general picture is, first, one of an active program in the inventory and mapping of wildland areas of Canada for a variety of purposes, but secondly, one of a much fragmented program in terms of continuity, organization, disciplines involved, and the land features that the investigators map. Many of the studies have been initiated by research organizations whose main policies and objectives focus on the examination of various classification techniques on small pilot study areas, and not on the inventory of specified areas of land for improved land management purposes.

A brief reference to extensive land inventory programs in another country will serve as an illustration of the broad type of land survey that we do not have at present in Canada, but which could be aimed for in any future programs in this country. The land research division of the Commonwealth Scientific and Industrial Research Organization in Australia has completed

${ }^{3}$ DAMMAN, A. W. H. 1959. Report On The Land Type Map Of The Area Between Serpentine River and Journoes Brook, Newfoundland. Canada, Dept. of Northern Affairs and National Resources. Unpub. Rep.

BLAKE, W. 1953. Vegetation And Physiography Of The Goose Bay Area, Labrador, and The Interpretation Of Forest Cover Types And Land Forms From Aerial Photographs. Unpub. M.Sc. Thesis McGill Univ., Montreal. 1953. 
surveys of over 500,000 square miles and has reported the results of its work in Land Research Series publications 1-14 (e.g., Perry et al. 1964). These surveys are conducted by a team of scientists (geologists, geomorphologists, botanists, pedologists, and foresters) who work together in the field and laboratory. The concepts and techniques used in the surveys have been described by Christian and Stewart (1953). A basic feature is that the areas of land are described in terms of "land systems" which are defined as "an area or group of areas throughout which there is a recurring pattern of topography, soils, and vegetation". The primary basis of separation of the land systems is geomorphology. The technique of surveying large areas in limited time is based on the interpretation of aerial photographs, and a basic assumption is that patterns distinguishable on airphotos are a reflection of land characteristics.

A comparable survey in the State of Victoria (Gibbons and Downes 1964) which used four different scales of mapping units-the "Land Component" (the smallest, most detailed unit of mapping), the "Land Unit", the "Land System", and the very broad "Land Zone", is another excellent illustration. The major difference in this approach is that the fundamental unit of land, the land component, is an area considered to be uniform within defined limits for each of the environmental characteristics-climate, parent material, topography, soil, and vegetation. "To recognize and characterize it, all and any features of the environment are considered, and moreover considered in interaction, so that the most important factor for those circumstances may be assessed. Geomorphology often forms the basis of characterization at the broadscale level of patterns (land zones and land systems)." In this survey each stage of mapping offers information of a certain kind, and mapping programs can proceed from the broader to more detailed scales as and where required according to the purpose of the survey and the information obtained at any stage.

\section{Proposed Methodology}

\section{Introduction}

Rowe (1962) in his review of several approaches used to classify land and soils stressed that purpose is implicit in all classification and different purposes lead to different kinds of classifications. Gibbons (1961) in his discussion of some misconceptions about soil surveys concluded that a universally applicable, general purpose classification does not exist, nor on theoretical grounds can it exist because of the many purposes devised by man for application in many different environments. One must therefore either develop a special classification for each purpose, or be content with a classification based on selected key criteria likely to correlate with most of the management problems that can be expected in the foreseeable future.

If our aim is to classify and map wildlands for more than one specific purpose, then we should accept the latter approach and consider at this point those criteria which we as foresters and wildland managers believe to be most important. Our investigational procedure should incorporate conditions that are common throughout Canada, such considerations as the state of 
development of forestry and wildland management, and the knowledge available from scientific observations and past experience.

\section{Regionalization}

Jurdant (1964a) noted that in all the different approaches to land classification in Canada there is a definite tendency to regionalize large territories in order to reduce geographic variation due to major changes in climate. geology, and physiography. There are the "Site Regions" of Hills (1960), the "Forest Regions" of Rowe (1959), the "Eco-regions" of Loucks (1962), and the Biogeoclimatic Zones of Krajina (1964). Whether we call them climatic regions, physiographic regions, vegetative regions, etc., is not as important as being certain that they provide a suitable geographic framework in which similar responses may be expected within similarly defined land units. A geographic framework of some sort is essential if our experience and data in one area are to be compared and related to other land areas at the provincial, regional, or national level.

In British Columbia, for example, we could combine and examine all the data and maps available from the following sources-the small-scale soils map being prepared by the Federal and Provincial Departments of Agriculture, Landforms of B.C. by Holland (1964), Biogeoclimatic zones of Krajina, Forest Regions of Canada, and the B.C. ARDA Agro-climatology Committee-and eventually develop a useful and improved geographic framework or "Wildland zonation" for B.C.

\section{Terms of Reference}

Within a regional framework, the factors we must consider in a basic procedure of wildland inventory in Canada are:

(1) the size of the country and the millions of acres that need to be examined;

(2) The present lack of professionally skilled personnel to carry out the task of examining much of this area within a reasonable period of time;

(3) the fact that much of the area of interest is not readily accessible;

(4) the availability of airphotos, of some sort, throughout all of Canada;

(5) the knowledge that much, if not all, of the area of interest has been glaciated and that the landscapes reflect this glacial history in fairly well defined landform and landform patterns.

If we intend to undertake wildland inventories, which will serve as basic references for improved management of our forestry, wildlife and recreation resources, and to complete maps and reports in a reasonable period of time, and at a reasonable cost, then we must keep in mind these terms of reference, for they will influence our basic classification techniques and the kinds of landscape units that we will establish. The first three items-the size of the country, its inaccessibility and the present absence of a large staff of professionally trained men-preclude the use of an inventory system based mainly on conventional field survey procedures and sampling techniques. 
Problems of scale enter into this question, too. Forestry and wildland management are still practised extensively rather than intensively and, as Rowe (1963) pointed out, a wildland classification at a smaller scale-a reconnaissance type of survey-_."in which rather large landscape patterns are delineated is what we need; and indeed, if the forested area of Canada is to be classified within a reasonable time, say within a decade, this scale of approach is the only one possible".

The inaccessibility of the areas of interest, combined with assets such as the availability of airphotos and the development of photo interpretation techniques brought about by the increasing use of aerial surveys since World War II, leads us to the consideration of a wildland classification system based on airphoto interpretation co-ordinated with field sampling. This combined airphoto field approach has a long history of use in Canada, and it has been accepted by investigators in all fields concerned with the planned development of natural resources.

\section{Classification and Mapping Procedures}

In dividing up and mapping the landscape into units for wildland management purposes, what features of the land should we look for, which ones can we identify and map in the field and on the airphotos, and which ones appear to be of value according to the knowledge which is presently available?

Throughout all the discussions on land classification techniques presented in the relevant forestry papers reviewed in the previous section, there is the basic agreement that, wherever airphoto techniques are combined with field investigations in the assessment of land resources, parent materials and topography (landforms) are a valuable, basic, and obvious starting point. This geomorphologic framework of landforms [landform being defined as the repetitive expression of the topography of the earth's surface, the parent materials of which it is composed and the geomorphic processes involved in its development (Miles 1963)] provides a satisfactory basis for the initial division of the landscape into ecologically significant units. It is within this geomorphic framework that soil and vegetation classifications can be undertaken with a maximum of efficiency (Jurdant 1964a), and the areal extent of relationships between soil and vegetation and the capabilities of these various units for selected purposes can be extended over adjacent landscapes.

It is evident that neither the soil profile nor the lesser vegetation can be of any direct use in the initial mapping stage using air photographic interpretation. For example, a Soil Series is defined in terms of profile characteristics which are not directly visible on the airphoto. As Curtis (1963) pointed out: "The Series also represents a grouping of soil individuals on the basis of selected criteria. Thus the series is a concept and does not represent a clearly defined natural phenomenon. There is no certainty that the boundary placed around these selected criteria will bear a close relationship to surface features. Indeed, the criteria used for its definition may be unsuited for photo interpretation".

This discussion was not introduced to leave you with the impression that we should not use the Soil Classification for Canada outlined by the National Soil Survey Committee $(1960,1963)$ in a Wildland Classification. My main purpose 
is to put the N.S.S.C. approach in correct perspective-soil profile types are not the objects of central interest in the classification of wildlands, but they will be very useful (i) in refining the units of land established, (2) as indicators of landscape ecology and history, and (3) as a basis of reference for intra- and inter-regional comparisons and correlations.

Similarly, lesser vegetation classifications cannot be used in the primary division of the landscape. The types cannot be identified and mapped on airphotos as readily as can features of the landform, tree vegetation, topography, and soil depth, etc. This does not mean that we should leave out vegetation in a wildland classification system. There are many people in the fields of wildlife, recreation, and forestry who are interested in the composition and distribution of present and potential vegetation cover, and its relationship to the landscape patterns and land management problems. It has been pointed out by Spilsbury that in forestry a knowledge of forest site types or plant associations is a most useful supplement in field checking boundaries and drawing attention to anomalies in the vegetation-soil patterns. Foresters have also relied on minor vegetation in site classification because it has been found to correiate quite well with soil moisture regime and type of humus layer (Rowe 1963).

What should be our procedure in fitting and combining drainage, soil and vegetation catenas into our initial geomorphological framework? How should we define and characterize our mapping units? First, I think that we should name our geomorphologic units along the lines of the work in Ontario and Australia, specifying the type, composition and structure of the material to which the name is applied. This procedure parallels that of the Soil Survey in naming Soil Series and that of the Geological Survey of Canada in naming their rock formations.

Now, each type of surficial deposit or landform will include within its boundaries two, three or more soil series, and vegetation types (the number will depend on the variations in surficial form, composition of the soil material and soil drainage conditions). For example, a coarse textured outwash terrace may contain only two soil catenary members, both in the rapidly and well drained end of the scale, whereas a drumlinized medium-textured till plain may contain a sizeable area of each of 4 soil catenary members-a well drained acid brown wooded, a podzol, an imperfectly drained gleyed podzol, and poorly drained gleysol components. With each of these soil series members will be associated a certain type of vegetation cover. I like the use of the term "land unit" to refer to each combination of soil series and vegetation type which has a specific physiographic position on a defined landform. A "land unit" corresponds to Hills' "physiographic site". Each land unit could have a designation comparable to our present use of forest capability classes and sub-classes (McCormack 1965), e.g., a specific segment of landform X, containing soil series "P" and vegetation type " 2 " could be shown as $\mathrm{X}_{2}{ }^{\mathrm{P}}$. Each land unit would have a capability rating for the main uses foreseen. The area of land composed of all the land units that are the catenary members on one parent material could be called the "Land Association".

If we had the time, the funds and the personnel, we could begin our 
mapping program at the "land unit" scale. This, however, is impractical in the present circumstances. The alternative approach is to initiate our wildland surveys at the land association level, putting boundaries around the land patterns or Associations, and then indicating as much as we can about the types of land units present, their proportionate occurrence and their spatial relationships (on cross-section or block diagrams). For example, I would use the following symbols to characterize the composition of the Lacustrine clay (X) basin in Prince George, composed of soil series Beaverley (B) (moderately well drained member), Pineview (P) (imperfectly drained member), and Aleza (A) (poorly drained member) and vegetation types 1,2 , and 3 :

X $\mathrm{B}-\mathrm{X} \underset{1}{\mathrm{~B}} \mathrm{P}-\underset{3}{\mathrm{P}} \mathrm{A}$. The $40-40-20$ percentage distribution of each component would be estimated from careful examination of land patterns on the airphotos.

\section{SUMMARY}

In summary, the proposed investigational procedures in wildland inventory and mapping, influenced and guided by specific terms of reference, are as follows:

(1) establish an acceptable regional framework;

(2) within this framework examine and map the landforms and landform patterns using airphoto interpretation combined with field examinations;

(3) identify, describe, and classify the catena of soil and vegetation types within each landform, and indicate their distribution and proportionate occurrence by combining airphoto interpretation techniques with field investigations;

(4) the next step is interpretation for use, conservation measures, etc., by "Land Associations" and "Land Units". The classification provides a framework into which knowledge can be keyed as it becomes available.

\section{REFERENCES}

BAJZAK, D. 1964. Interpreting Phytosociologic Forest Site Types From Aerial Photographs. Project NF-67. Dept. of Forestry of Canada, Forest Res. Branch. Mimeo 64-N-12. St. Johns, Nfld.

BICKERSTAFF, A. 1963. Forestry Considerations in Canadian Land-Use Planning. For. Chron., 39: (4). 1963.

BROWN, W. G. E. 1956. Roads and Land. Timber of Canada. February, 1956.

CHRISTIAN, C. S., and STEWART, G. A. 1953. General Report on Survey of KatherineDarwin Region 1946, CSIRO Aust. Land Res. Ser. No. 1.

CROSSLEY, D. I. 1951. The Soils On The Kananaskis Forest Experiment Station In The SubAlpine Forest Region In Alberta. Canada, Dept. of Resources and Development. Silvicultural Res. Note. No. 100.

CURTIS, L. F. 1963. Soil Classification and Photo Interpretation. Vol. XIV. Transactions Of The Symposium On Photo Interpretation. Delft, The Netherlands. Sept. 1962.

DAY, J. H., and LEAHEY, A. 1957. Reconnaissance Soil Survey Of The Slave River Lowland In The Northwest Territories Of Canada. Experimental Farms Service. Canada Dept. of Agriculture. Ottawa.

DUFFY, P. J. B. 1965. A Forest Land Classification For The Mixedwood Section Of Alberta. Dept. of Forestry of Canada Pub. No. 1128. 
FULTON, R. J. 1962. Surficial Geology Kamloops Lake Map Sheet. Canada Dept. of Mines and Tech. Surveys Geological Survey of Canada.

GIBBONS, F. R. 1961. Some Misconceptions About What Soil Surveys Can Do. Jour. Soil Sci. Vol. 12 No. 1, 1961.

GIBBONS, F. R., and DOWNES, R. G. 1964. A Study Of The Land In Southwestern Victoria. Soil Conservation Authority, Victoria, Australia.

GIMBARZEVSKY, P. 1964. The Significance Of Landforms In The Evaluation Of Forest Land. Woodlands Review Section Pulp and Paper Magazine of Canada, June, 1964.

HARE, F. K. 1959. A Photo-Reconnaissance Survey Of Labrador-Ungava. Geogr. Memoir 6. Geogr. Branch, Mines and Tech. Surveys.

HILLS, G. A. 1960. Regional Site Research. For. Chron. 36:(4). 1960.

1961. The Ecological Bases For Land-Use Planning. Ont. Dept. of Lands and Forests, Technical Series. Res. Report No. 46.

HILLS, G. A., and PIERPOINT, G. 1960. Forest Site Evaluation In Ontario. Ontario Dept. of Lands and Forests. Technical Series. Research Report No. 42.

HILLS, G. A., PORTELANCE, R., and BOISSONNEAU, A. N. 1960. The Glackmeyer Report of Multiple Land-Use Planning. Ontario Dept. of Lands and Forests.

HOLLAND, S. S. 1964. Landforms Of British Columbia. A Physiographic Outline. British Columbia Dept. of Mines and Petroleum Res. Bull. No. 48.

JEFFREY, W. W., BAYROCK, L. A., LUTWICK, L. E., and DORMAAR, J. F. 1964. LandVegetation Typology In The Upper Oldman River Basin, Alberta. Dept. of Forestry of Canada. (In Press)

JURDANT, M. 1964a. Photo Interpretation And Forest Land Classification. Woodlands Review Section. Pulp and Paper Magazine of Canada. October, 1964.

1964b. Carte Phytosociologique et Forestière de la Forêt Expérimentale De Montmorency. Publication du Ministère des Forêts No. 1046F.

KRAJINA, V. J. 1964. Revision Of Biogeoclimatic Regions and Zones In British Columbia. Appendix $\mathrm{H}$, in Ecology Of The Forests Of The Pacific Northwest. 1963 Progress Report on NRC Grant T-92, University of British Columbia, Vancouver.

LACATE, D. S. 1965. Forest Land Classification For The University Of British Columbia Research Forest. Dept. of Forestry of Canada Pub. No. 1107.

LACATE, D. S., ARLIDGE, J. W. C., SPROUT, P. N., and MOSS, A. 1965. Forest Land Classification and Interpretations For Management In The Spruce Working Circle, Tree Farm License No. 9, Okanagan Valley, B.C. Interim Report. B.C. Dept. of Agriculture, Kelowna, B.C

LAJOIE, P. G. 1960. Soil Survey of Argenteuil, Two Mountains and Terrebonne Counties, Quebec. Canada Dept. of Agriculture. Res. Branch.

LEAHEY, A. 1953. Preliminary Soil Survey Of Lands Adjacent To The MacKenzie Highway In The Northwest Territories. Experimental Farms Service. Canada Dept. of Agriculture, Ottawa.

LOUCKS, O. L. 1962. A Forest Classification For The Maritime Provinces. Proc. of The Nova Scotian Institute of Science. Vol. 25, Part 2, 1959-60.

LYNN, R. J., and ZOLTAI, S. C. 1965. The Greta Lake Road Reference Area Geraldton Site District Site Region 3W. Ont. Dept, of Lands and Forests, Technical Series. Res. Report No. 60 .

McCORMACK, R. J. 1965. Outline of the Canadian Land Capability Classification for Forestry, and Guidelines for Mapping. Papers prepared for Canada Land Inventory, ARDA, March, 1965, Ottawa.

MILES, R. D. 1963. A Concept Of Landforms, Parent Materials And Soils, In Airphoto Interpretation Studies For Engineering Purposes. Vol. XIV. Transactions Of The Symposium On Photo Interpretation. Delft, The Netherlands, Sept. 1962.

MUELLER-DOMBOIS, D. and JAMESON, J. S. 1963. A Site Classification For Forest Inventory Purposes In South Central Manitoba Based On Ecological Relationships. Dept. of Forestry of Canada, Forest Res. Branch. Mimeo 63-MS-18.

NATIONAL SOIL SURVEY OF CANADA. 1960. Report of The Meeting Held At The Ontario Agricultural College, Guelph. February, 1960.

1963. Report On The Fifth Meeting Held At Winnipeg, Manitoba. March, 1963. 
ODYNSKY, W., LINDSAY, J. D., REEDER, S. W. and WYNNYK, A. 1961. Reconnaissance Soil Survey Of Beaverlodge And Blueberry Mountain Sheets. Research Council of Alberta, Report No. 81.

PERRY, R. A., SLEEMAN, J. R., TWIDALE, C. R., PRICHARD, C. E., SLATYER, R. O. LAZARIDES, M., and COLLINS, F. H. 1964. General Report On Lands Of The Leichhardt-Gilbert Area, Queensland, 1953-54. C.S.I.R.O. Land Research Series No. 11, Melbourne, Australia.

PIERPOINT, G. 1962. The Sites Of The Kirkwood Management Unit. Ont. Dept. of Lands and Forests, Res. Report 47.

RITCHIE, J. C. 1961. Soils And Minor Vegetation Of Pine Forests In Southeast Manitoba. Dept. of Forestry of Canada, Forest Res. Division. Technical Note. No. 96.

ROWE, J. S. 1959. Forest Regions of Canada. Canada, Dept. Northern Affairs and National Resources, Forestry Branch. Bull. 123.

1962. Soil, Site And Land Classification. For. Chron. 38:(4), 1962.

1963. Factors Which Should Be Considered In Classifying Lands For Forestry. Introduction To An Open Discussion, National Soil Survey Committee Meetings. Winnipeg, March, 1963

SASKATCHEWAN SOIL SURVEY. 1960. Schematic Physiographic And Soil Map Of The Northern Provincial Forests. Sask. Soil Survey Report No. 14.

SMITH, R. E., EHRLICH, W. A., JAMESON, J. S., and CAYFORD, J. H. 1964. Report Of The Soil Survey Of The South-Eastern Map Sheet Area. Manitoba Soil Survey. Soils Report No. 14

SPILSBURY, R. H., ARLIDGE, J. W. C., KESER, N., FARSTAD, L. and LACATE, D. S. 1965. A Co-operative Study Of The Classification Of Forest Land. Forest-Soil Relationships In North America. Oregon State University Press, Corvallis.

SPROUT, P. N., LACATE, D. S., and ARLIDGE, J. W. C. 1964. Forest Land Classification Survey Southern Interior Of British Columbia McGillivray Lake. A Co-operative Report, Dept. of Forestry of Canada, Mimeo 64-BC-6, Victoria, B.C.

SPURR, S. H. 1904. The Ambivalence Of The Forestry Profession. Jour. For. 62:(11). 1964

STAEBLER, G. R. 1965. What Should Be The Goals Of The Society Of American Foresters? Jour. For., 63:(10), 1965.

TOMLINSON, R. F. 1963. The Application Of Photo-Interpretive Techniques To Geographical And Planning Studies In Canada. Vol. XIV. Transactions Of The Symposium On Photo Interpretation. Delft, The Netherlands. Sept., 1962 